\title{
Macro and Micronutrients Assessment in Transgenic an Non- Transgenic Soybean Seeds by Inductively Coupled Plasma Optical Emission Spectroscopy
}

\section{Marco A. Z. Arruda (PQ), Tatiana Caurin (IC)}

\begin{abstract}
The main goal of this work was to evaluate macro ( $\mathrm{Ca}$ and $\mathrm{P})$ and micro $(\mathrm{Cu}, \mathrm{Fe}$ and $\mathrm{Zn})$ nutrients in transgenic (T) and non-transgenic (NT) soybean seeds by inductively coupled plasma optical emission spectroscopy. A multi-elemental method was developed, using a certified reference material (tomato leaves 1573a) for checking the accuracy, and rhodium as internal standard. The method was efficient to determine the analytes, allowing the comparison among different soybean seeds samples.
\end{abstract}

Soybean seeds, Multi-elemental analysis, ICP OES

\section{Introduction}

Comparative studies between transgenic and nontransgenic soybean have suggested changes in proteome, metalome and enzymes of transgenic soy. This indicates that the genetically modified organism can present other features beyond tolerance to glyphosate, as well as changes in all its metabolism. 1, 2, 3

Thus, comparative studies are necessary involving $T$ and $N T$ soybean, regarding the concentration of macro and micronutrients. For this task, a multi-elemental method was carried out helping the evaluation of genetic modification. ${ }^{4}$

\section{Results and Discussion}

ICP OES parameters were optimized using a standard solution of each analyte. The optimized conditions are shown in Table 1.

Table 1. Operating conditions for ICP OES.

\begin{tabular}{|c|c|}
\hline Spray Chamber & Cyclonic \\
\hline Nebulizer & Concentric \\
\hline RF incident power (W) & 1300 \\
\hline $\begin{array}{lll}\begin{array}{l}\text { Nebulizer } \\
\left(\text { L. } \min ^{-1}\right)\end{array} & \text { Ar } & \text { flow } \\
\end{array}$ & 0.5 \\
\hline $\begin{array}{lll}\text { Auxiliary } \\
\left(\text { L. } \min ^{-1}\right)\end{array} \quad$ Ar $\quad$ flow & 0.5 \\
\hline Replicates & 3 \\
\hline Plasma view & Axial \\
\hline Line, $\lambda(\mathrm{nm})$ & $\begin{array}{l}\text { Zn 213.856; Fe } \\
\text { 273.074; Cu 324.754; P } \\
\text { 185.942; Ca 184.006 }\end{array}$ \\
\hline
\end{tabular}

The method was assessed using the certified reference material tomato leaves (CRM 1573a). Approximately $0.25 \mathrm{~g}$ of material was decomposed with $1 \mathrm{~mL}$ of $\mathrm{H}_{2} \mathrm{O}_{2}$ and $6 \mathrm{~mL}$ of $\mathrm{HNO}_{3}$ sub-boiled, using a microwave oven. The program used was: 5 min @ 400 W, 20 min @ 790 W, 3 min@320W, 3min@0W.

After decomposition, samples were evaporated until ca. $1 \mathrm{~mL}$. After filtration, samples were transferred to a $10 \mathrm{~mL}$ volumetric flask and diluted with $\mathrm{HNO}_{3} 0.2 \%(\mathrm{v} / \mathrm{v})$. The results are showed in Table 2.

Table 2. Recovery of analytes in CRM, and limits of detection and quantification using ICP OES.

\begin{tabular}{cccc}
\hline Element & $\begin{array}{c}\text { Recovery } \\
(\%)\end{array}$ & $\begin{array}{c}\mathrm{LD} \\
\left(\mu \mathrm{g} . \mathrm{L}^{-1}\right)\end{array}$ & $\begin{array}{c}\mathrm{LQ} \\
\left(\mu \mathrm{g} \cdot \mathrm{L}^{-1}\right)\end{array}$ \\
\hline $\mathrm{Ca}$ & $95.4 \pm 0.8$ & 1.0 & 4.0 \\
\hline $\mathrm{P}$ & $111.5 \pm 0.3$ & 12.4 & 41.2 \\
\hline $\mathrm{Cu}$ & $96.1 \pm 0.9$ & 0.5 & 1.7 \\
\hline $\mathrm{Fe}$ & $79.2 \pm 1.2$ & 52.5 & 174.9 \\
\hline $\mathrm{Zn}$ & $95.7 \pm 0.2$ & 0.2 & 0.8 \\
\hline
\end{tabular}

\section{Conclusions}

The multi-elemental method was efficient to determine $\mathrm{Ca}, \mathrm{P}, \mathrm{Cu}, \mathrm{Fe}$ and $\mathrm{Zn}$, since the results obtained using the standard reference material was satisfactory, in terms of accuracy.

Data obtained from the analysis of transgenic and non-transgenic soybean samples are being processed and will be presented later.

\section{Acknowledgement}

The authors are thankful to the National Counsel of Technological and Scientific Development (CNPq) for all the financial support and University of Campinas.

\footnotetext{
Barbosa, H.S.; Arruda, S.C.C.; Azevedo, R.A. and Arruda, M.A.Z. Anal. Bioanal. Chem. 2012, 402, 299-314.

${ }^{2}$ Oliveira, S. R.; Menegário, A. A. and Arruda, M. A. Z. Metallomics 2014, 6, 1832-1840.

3 Arruda, S.C.; Barbosa, H.S.; Azevedo, R. A. and Arruda, M. A. J. of Proteomics 2013, 93, 107-116.

${ }^{4}$ Suliburska, J. and Krejpcio, Z. J. F. Scie. Tech. 2014, 51, 589-594.
} 